\title{
Estimates of Genotype $x$ Environment Interactions and Heritability of Black Point in Durum Wheat
}

\author{
Hasan KILIÇ', , Abuzer SAĞIR²), Yunus BAYRAM ${ }^{1)}$ \\ 1) Southeastern Agricultural Research Institute,Diyarbakır,TR-21110,Turkey; kilichasan@yahoo.com; ybayram@hotmail.com \\ ${ }^{2)}$ University of Dicle, Faculty of Agriculture, Plant Protection Department, Diyarbakir, TR-21280, Turkey; asagir@dicle.edu.tr
}

\begin{abstract}
Experiments were carried out in four different locations with 14 durum wheat genotypes in two successful seasons of 1999-2000 and 2000-2001. Black point disease of genotypes was evaluated by interactions of genotypes and environment as well as heritability $\left(h^{2}\right)$. It was found that black point disease affected differently in different locations and growing seasons. This indicates that the genotypes have different adaptation ability for traits studied in different locations. Heritability rate that variance analyzes accepted means squares calculated was found as phenotypic variance rate of genotypic variance was found as $49 \%$. Variance of genotype $\mathrm{x}$ location $\mathrm{x}$ year was bigger than other variance components. Genotype x year variance was bigger than genotype $\mathrm{x}$ location variance too. The heritability of black point disease was founded moderate. In addition to one of factors on the black point disease genotype also environment $\mathrm{x}$ genotype interactions were found effective. According to evaluation of black point disease, the highest value was obtained from 'Sorgül' (2.7\%), 'Dicle-74' (2.56\%) and 'Gidara-II' (2.32\%) varieties; the least value was obtained from 'Balcali-2000' variety (0.64\%). Alternaria spp., Phoma sp, Fusarium spp., Helminthosporium spp., and Stemphylium spp., fungi were isolated from the grain affected by black point diseases.
\end{abstract}

Keywords: wheat varieties, black point, environment x genotype interaction, heritability.

\section{Introduction}

Wheat is one of the world's three most important cereal crops (the other two are maize and rice) and it has the widest distribution of any cereal. The crop is primarily grown for its grain, which is consumed as human food. Durum wheat is a minor crop, grown in only 8 to $10 \%$ all the wheat cultivated area.

Combine analyses done over the multi location are used for determination of genotype $\mathrm{x}$ environment interaction and theirs variance components. This method occupies important place to estimate the heritability and selection of characters (Crossa, 1990). Information about phenotypic stability is useful for the selection of crop varieties as well as for breeding programs (Akçura et al., 2005). The phenotypic performance of a genotype is not necessarily the same under diverse agro-ecological conditions (Ali $e t$ al., 2003). Some genotypes may perform well in certain environments, but, fail in several others. Genotype-environment $(\mathrm{GE})$ interactions are extremely important in the development and evaluation of plant varieties because they reduce the genotypic stability values under diverse environments (Hebert et al., 1995).

Black point disease is characterized by a brown black discoloration of the embryos of the wheat (Triticum durum L.) kernels. Genetic factors are important in durum susceptibility to black point. Empirical multi location registration trials have long since show durum cultivars differ considerably in black point susceptibility (Geves, 1994). The disease can be a problem in wheat areas receiving heavy rainfall during the early stages of kernel development (Greaney and Wallace, 1943; Kilpatrick, 1968). The disease can reduce the commercial grade of wheat causing economic losses to wheat producers. Besides, TMO (Turkish Grain Council) assesses the grain as called black point over the $10 \%$ injury. Black pointed kernels have also an adverse effect on the quality of the flour (Rees $e t$ al., 1984; Lorenz, 1986). This disease is resistance under different genetic control in certain cultivars (Conner and Davidson, 1988).

Alternaria sp., Cladosporium sp., Drechslera sp., Epicoccum sp., Fusarium sp., and Phoma sp., were isolated from black pointed kernels of wheat cultivars grown in Central Anatolia, Southern Anatolia and Çukurova regions in Turkey (Biçici and Çınar, 1988; Tunalı and Aktaş, 1999; Sağır and Akınc1, 2001). In all these studies fungi were determined by plating the intact kernels on agar medium or on moistened filter paper. The presence of fungal mycelium in different parts of black pointed kernels has been determined by microscopically observations (Bhowmink, 1969; Lorenz, 1986; Agrawal et al., 1987).

In addition, recent studies have determined some markers for identifing for black point disease. Markers have been identified on chromosomes $2 \mathrm{H}$ and $5 \mathrm{H}$ (Fox et. al., 2004). Sulman et al. (2003) also reported levels of 
heritability from 39 to $70+\%$ in a number of populations suggesting that development of resistance to this grain defect was readily achievable through selection.

This present study was undertaken to describe the fungi relation with genotype $\mathrm{x}$ environment interactions as well as heritability $\left(h^{2}\right)$. In this study 14 durum wheat cultivars planted in four different locations in south-eastern Anatolia in Turkey.

\section{Materials and methods}

According to plant materials and field conditions fourteen durum wheat genotypes were designed by a randomized complete block design with 4 replications. The names and code numbers of genotypes/cultivars of durum wheat genotypes are given in Tab. 1 . The experiment was

Tab 1. Pedigrees and other information related to genotypes used in 8 environments.

\begin{tabular}{|c|c|c|}
\hline Code & Cultivars & Pedigrees \\
\hline 1 & 'Altintoprak-98' & Altar84/AOS “S"-CD67124.1Y-503M-OY \\
\hline 2 & 'Aydin-93’ & OMRABİA “S” \\
\hline 3 & 'Ceylan-95' & Stk "S"/Rabi "S" \\
\hline 4 & 'Dicle-74' & $\begin{array}{c}\text { Cocorit } 71=\mathrm{RA}_{\mathrm{E}}-\mathrm{TC}^{4} \mathrm{x} \text { stw63// } \\
\text { AA "S" D.27617-18M-6Y-OM }\end{array}$ \\
\hline 5 & 'Diyarbakır-81' & $\begin{array}{l}\text { LD. } 393 \times \text { Belle-Tc }{ }^{2} \mathrm{Cit} 71 . \\
\text { SE:0.364-1S- } 4 \text { S-OS }\end{array}$ \\
\hline 6 & 'D. 5456 & (hybridization) $100 \mathrm{D}$ X Semolina \\
\hline 7 & 'Ege-88' & JO/AA//FG CM9799-126M-1M-4Y-0M \\
\hline 8 & 'Firat-93' & $\begin{array}{l}\text { AA "S" / Vol "S" //Fg "S" /3/Shwa } \\
\text { "s" CM:2798-6-1M-2Y-1Y-OM }\end{array}$ \\
\hline 9 & 'Gidara-II' & Gidara \\
\hline 10 & 'Ozberk' & $\begin{array}{l}\text { Fg"s"/Gr"s"//CandealI/4/Grebe/3/Ctfn/ } \\
\text { Fg"s"//Ptl"s"/5/Akb.073.44/Yerli/6/Car"s" }\end{array}$ \\
\hline 11 & 'Harran-95' & $\begin{array}{l}\text { Korifla (D.S.15 Gieger) =Korifla } \\
\text { CD523-3Y-1Y-2M.OY }\end{array}$ \\
\hline 12 & 'Sarıçanak-98' & Daki "S" \\
\hline 13 & 'Sorgul' & Local population \\
\hline 14 & 'Balcali 2000' & 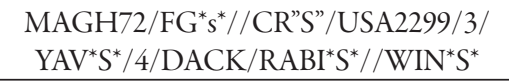 \\
\hline
\end{tabular}

performed under rainfed and supplemented irrigation conditions in the 1999-2000 and 2000-2001 growing seasons in 4 different locations in South-eastern Anatolia: Diyarbakır-1, Diyarbakır-2, Akçakale and Ceylanpınar. The seeds were sown using an experimental drill in $1.2 \mathrm{~m}$ x $7 \mathrm{~m}$ plots consisting of 6 rows with a $20 \mathrm{~cm}$ row space. The seeding rates were about 450 seeds per $\mathrm{m}^{2}$ for all locations. The plots were fertilized with $60 \mathrm{~kg} \mathrm{~N} \mathrm{ha}^{-1}$ and 60 $\mathrm{kg} \mathrm{P}_{2} \mathrm{O}_{5}$ ha $^{-1}$ at the planting and $40 \mathrm{~kg} \mathrm{~N}$ ha-1 in spring at stem elongation for Diyarbakır rainfed condition, $50 \mathrm{~kg}$ $\mathrm{P}_{2} \mathrm{O}_{5} \mathrm{ha}^{-1}$ and $50 \mathrm{~kg} \mathrm{~N} \mathrm{ha}^{-1}$ at planting and $50 \mathrm{~kg} \mathrm{~N} \mathrm{ha}^{-1}$ in spring at stem elongation for Ceylanpınar and Akçakale rainfed conditions. However, plots were fertilized with 80 $\mathrm{kg} \mathrm{N} \mathrm{ha}{ }^{-1}$ and $80 \mathrm{~kg} \mathrm{P}_{2} \mathrm{O}_{5}$ ha $^{-1}$ at planting and $60 \mathrm{~kg} \mathrm{~N}$ $\mathrm{ha}^{-1}$ in spring at stem elongation for Diyarbakır irrigation condition. For Plots $1.2 \mathrm{~m}$ x $5 \mathrm{~m}$ size were harvested by a combined harvester All field conditions such as growing seasons, environments, soil properties, fertilization treatments, and the rainfall at each location during the growing period and sowing date and harvesting date are summarized in Tab. 2.

Percentage of Black point (\%), is determined by counting the number of infected kernels in given sample and dividing by the total of number of seeds in the sample. All the experiments were arranged in a completely randomized design. Data on the incidence of fungi and, the percentage of black point disease of grain were subjected to an angle (arc sin) transformation prior to analysis of variance (ANOVA) procedures of JMP-5.0.1 (SAS Institute Inc. 2002). Means were compared with the level of $5 \%$ for Tukey Range Test.

Five fungal isolates were obtained from contaminated seeds of 14 wheat cultivars. Contaminated seeds have a black point; this characteristics symptom of the disease caused by Alternaria spp., Phoma sp, Fusarium spp., Helminthosporium spp. and Stemphylium spp. Spores of all varieties from this isolate were put into Petri dishes with PDA (potato-dextrose-agar) culture medium. After seven days at a temperature of $24 \pm 2^{\circ} \mathrm{C}$ and a photoperiod of 12 $\mathrm{h}$, small blocks of the culture medium with fungus mycelia were transferred to $250 \mathrm{ml}$ Erlenmeyer flasks with $25 \mathrm{ml}$ of

Tab. 2. Site description and agronomic details

\begin{tabular}{cccccccccc}
\hline Code & $\begin{array}{c}\text { Growing } \\
\text { season }\end{array}$ & Environments & Soil properties & \multicolumn{2}{c}{$\begin{array}{c}\text { Fertilization } \\
\mathrm{kg} \mathrm{h}^{-1}\end{array}$} & $\begin{array}{c}\text { Rain fall } \\
\mathrm{mm}\end{array}$ & $\begin{array}{c}\text { Irrigation } \\
\mathrm{mm}\end{array}$ & $\begin{array}{c}\text { Sowing } \\
\text { date }\end{array}$ & $\begin{array}{c}\text { Emergency } \\
\text { date }\end{array}$ \\
\hline & & & & $\mathrm{N}$ & $\mathrm{P} 2 \mathrm{O} 5$ & & & \\
E1 & $2000-2001$ & Diyarbakır -1 & $\mathrm{pH}=7.4$ clay-silt & $60+60$ & 60 & 245 & - & 01.11 .99 & 16.01 .00 \\
E2 & $1999-2000$ & Diyarbakır -2 & $\mathrm{pH}=7.4$ clay-silt & $80 \mathrm{a}+60 \mathrm{~b}$ & $80 \mathrm{a}$ & 245 & 150 & 01.11 .99 & 16.01 .00 \\
E3 & $2000-2001$ & Diyarbakır -1 & $\mathrm{pH}=7.4$ clay-silt & $60-60$ & 60 & 537 & - & 09.11 .00 & 27.11 .00 \\
E4 & $1999-2000$ & Diyarbakır -2 & $\mathrm{pH}=7.4$ clay-silt & $80+60$ & 80 & 537 & 100 & 09.11 .00 & 27.11 .00 \\
E5 & $1999-2000$ & Akçakale & $\mathrm{Ph}=7.8$ clay-silt & $50+50$ & 50 & 212 & - & 28.10 .99 & 25.12 .99 \\
E6 & $2000-2001$ & Akçakale & $\mathrm{Ph}=7.8$ clay-silt & $50+50$ & 50 & 319 & - & 27.11 .00 & 16.12 .00 \\
E7 & $1999-2000$ & Ceylanpınar & $\mathrm{Ph}=7.8$ clay-silt & $50+50$ & 50 & 156 & - & 11.11 .99 & 14.12 .00 \\
E8 & $2000-2001$ & Ceylanpınar & $\mathrm{Ph}=7.8$ clay-silt & $50+50$ & 50 & 295 & - & 24.11 .00 & 18.12 .00 \\
\hline
\end{tabular}

a Seed-bed; b Stem elongation Source: Anonim (2001) 
Tab. 3. Total rain and irrigation $(\mathrm{mm})$ and average maximum and minimum temperatures $\left({ }^{\circ} \mathrm{C}\right)$ for Diyarbakır, Ceylanpınar and Akçakale, (May) 2000 to 2001.

\begin{tabular}{|c|c|c|c|c|c|}
\hline & & & Irrigation & $\begin{array}{r}\text { Temp } \\
\left({ }^{\circ}\right. \\
\end{array}$ & $\begin{array}{l}\text { ture } \\
\text { iv }\end{array}$ \\
\hline $\begin{array}{c}\text { Location, } \\
\text { year }\end{array}$ & Period & $\begin{array}{l}\text { Rain } \\
(\mathrm{mm}) \mathrm{x}\end{array}$ & $\begin{array}{l}\text { Amount } \\
(\mathrm{mm}) \mathrm{y}\end{array}$ & Min. & Max. \\
\hline \multicolumn{6}{|c|}{ Diyarbakır -1 } \\
\hline 2000 & 1-31 May & 6.1 & $50(1)$ & 10.8 & 28.4 \\
\hline 2001 & 1-31 May & 86.9 & $50(1)$ & 9.8 & 23.5 \\
\hline \multicolumn{6}{|c|}{ Diyarbakır -2 } \\
\hline 2000 & 1-31 May & 6.1 & NA & 10.8 & 28.4 \\
\hline 2001 & 1-31 May & 86.9 & NA & 9.8 & 23.5 \\
\hline \multicolumn{6}{|c|}{ Ceylanpınar } \\
\hline 2000 & 1-31 May & 7.2 & $\mathrm{NA}$ & 10.0 & 37.4 \\
\hline 2001 & 1-31 May & 47.2 & NA & 9.0 & 38.0 \\
\hline \multicolumn{6}{|c|}{ Akçakale } \\
\hline 2000 & 1-31 May & 10.6 & NA & 12.5 & 30.5 \\
\hline 2001 & 1-31 May & 52.1 & NA & 11.3 & 27.9 \\
\hline
\end{tabular}

w Minimum and maximum mean temperatures during grain filling period. $\mathrm{x}$ Amount of rain during grain filling period .

y Amount of irrigation during grain filling period (number of applications).

z NA = not applicable

Source: Anonim (2001)

modified liquid Fries medium (Luke and Wheeler, 1955) or $1000 \mathrm{ml}$ Erlenmeyer flasks with $200 \mathrm{ml}$ of modified Fries medium and small balls of glass. Fungus culture was incubated for 21 days in an orbital incubator at a temperature of $24 \pm 2^{\circ} \mathrm{C}$. After incubation, the fungus mycelium was separated from the liquid phase by filtering through Whatman No. 1 filter paper. The filtrate was concentrated at $45^{\circ} \mathrm{C}$ in a steam bath in a vertical flux chamber to $10 \%$ of its original volume (Barbieri et al., 1997).

Statistical analyses. A combined analysis of variance was first undertaken across the test environments. Then broad-sense heritability was determined by means of variance components calculated from expected means squares from the ANOVA as proposed by Sabanc1 (1992), Demir and Turgut (1999) by using the following formula;

$\mathrm{H}=\mathrm{Q}^{2} / \mathrm{Q} 2 \mathrm{ph}=\mathrm{Q}^{2}{ }_{\mathrm{g}} /\left(\mathrm{Q}^{2} \mathrm{~g}_{\mathrm{g}}+\mathrm{Q}_{\mathrm{gl}}^{2} / \mathrm{l}+\mathrm{Q}_{\mathrm{gy}}^{2} / \mathrm{y}+\right.$ $\mathrm{Q}^{2}{ }_{\mathrm{gl}} /$ ly $+\mathrm{Q}^{2}{ }_{\mathrm{e}} /{ }_{\mathrm{rly}}$ ) where $\mathrm{Q}^{2}$ is the genotypic variance; $\mathrm{Q}^{2} \mathrm{ph}$ is the phenotypic variance; $\mathrm{Q}_{\mathrm{gl}}^{2}$ is the variance for interaction of genotypes with locations; $\mathrm{Q}_{\mathrm{gy}}^{2}$ is the variance for genotypes with years; $\mathrm{Q}_{\mathrm{gy}}^{2} \mathrm{l}$ is the variance for genotypes, locations and years; and $\mathrm{Q}_{\mathrm{c}}^{2}$ is the variance for error. All statistical analyses were performed by using SAS (Statistical Analyses Systems) program (SAS Institute, 2002).

\section{Results and discussion}

In this study, black pointed kernels appeared to have high frequency of Alternaria spp.(Tab. 4), Sağır and Akıncı (2001) and Sönmez et al. (2005) reported that they found Alternaria spp. (84.3\%), Fusarium spp (9.3\%) and Helminithosporium sp. (6.2\%) from isolated black pointed kernels in south-eastern Anatolia. The occurrence of $\mathrm{Al}$ ternaria alternata as a dominant species on black pointed kernels and other fungi, except for Stemphylium botryosum and Fusarium culmorum, agrees with other reports (Greaney and Wallace, 1943; Rana and Gupta, 1982; Khanum et al., 1987; Conner and Kuzyk, 1988; Fakir et al., 1989; Zhang et al., 1990; Fernandez et al., 1994).

The environmental factors, especially high rainfall at anthesis or milk development stages were probably responsible for black point as previously reported (Kilpatrick, 1968; Adlaka and Joshi, 1974; Conner et al., 1990).

Estimates for pertinent variance components were given in Tab. 5. While genotype $x$ location interactions, year $x$ location interactions, locations, years and genotypes were highly significant $(\mathrm{P}<0.01)$, the genotype $\mathrm{x}$ location $\mathrm{x}$ year interactions was important $(\mathrm{P}<0.05)$. The presence of genotype $\mathrm{x}$ location interactions indicates that particular genotypes tended to rank differently in black point rate at different locations; Moreover, the genotype x year interaction indicates that genotypes tended to rank differently in black point rate at different years (Tab. 5).

The result of combined analysis over the years and locations indicated that there were significant $(\mathrm{P}<0.005$ level) differences between varieties. While the highest percentage of black point was obtained from 'Sorgül' cultivar (16.85\%) in Diyarbakır-1 location in 2000/2001 growing season, the lowest percentage black rate were obtained from 'Balcali-2000' cultivar (0.05\%) in Diyarbakır-2 and Akçakale locations in 1999/2000 growing season (Tab. 6).

The local 'Sorgül' and 'Dicle-74' were the most susceptible and the 'Balcali-2000' cultivar was the most resistant to black point. These results were also reported by Southwell at all (1980). They reported that resistance of durum

Tab. 4 . The incidence of fungi detected by black pointed kernels of four locations in 2000 and 2001

\begin{tabular}{lccccccc}
\hline \multirow{2}{*}{ Locations } & \multicolumn{7}{c}{ Percentage of wheat kernels contaminated with } \\
\cline { 2 - 7 } & Alternaria spp. & Fusarium spp & Phomasp & Stemphylium spp. & Helminthosporium spp & Others & Total \\
\hline Diyarbakır-1 & 80.0 & - & - & - & 4.8 & 20 & 100 \\
Diyarbakır-2 & 69.0 & 4.8 .0 & 11.9 & 7.1 & - & 2.4 & 100 \\
Akçakale & 69.0 & 8.0 & 15.4 & - & - & 7.7 & 100 \\
Ceylanpınar & 69.2 & 6.2 & - & 3.70 & 7.40 & - & 100 \\
Means & 70.4 & 4.93 & 8.64 & & 4.93 \\
\hline
\end{tabular}


Tab. 5. Analysis of variance and variance components for black point percentage of 14 durum wheat genotypes

\begin{tabular}{l|c|c|c|c|}
\hline \multicolumn{1}{|c}{$\begin{array}{c}\text { Source of } \\
\text { variation }\end{array}$} & df & $\begin{array}{c}\text { Sum of } \\
\text { Square }\end{array}$ & $\begin{array}{c}\text { Means } \\
\text { Square }\end{array}$ & F \\
\hline Model & 135 & 11698.325 & 86.6543 & Prob > F \\
\hline Replications (LxY) & 24 & 122.9099 & 5.12124 & 783.0523 \\
\hline Genotypes (G) & 13 & 451.2995 & $34.7153^{* *}$ & 398.9437 \\
\hline Years (Y) & 1 & 2813.5177 & $2813.51^{* *}$ & 307.5568 \\
\hline Locations (L) & 3 & 4300.2306 & $1433.41^{* *}$ & 1.4253 \\
\hline GxY & 13 & 131.4421 & $10.1109^{* *}$ & 9.6619 \\
\hline GxL & 39 & 333.4326 & $8.54955^{* *}$ & 2.8141 \\
\hline YxL & 3 & 3315.1671 & $1105.05^{* *}$ & 2.3795 \\
\hline GxYxL & 39 & 230.3256 & $5.90578^{*}$ & 1.6437 \\
\hline Pooled Error & 312 & 1121.020 & 3.5930 & Prob > F \\
\hline Corrected Total & 447 & 12819.345 & & \\
\hline ** significant at 0.01 probability level. ${ }^{*}$ significant at 0.05 probability level.
\end{tabular}

wheat cultivars to black point caused by Alternaria alternata was evaluated in the field in northern New South Wales. The cultivars tested showed a range of infection levels. The most susceptible cultivars were 'Duramba' and 'Gaza', while those showing the greatest resistance were 'Wandell', 'Wascana' and 'Aus 15350'.

Heritability: To determine proportional effect of environment factors on black point dividend variance resources were given in Tab. 7 .
Gx L x Y effects were fairly large (2.32) relative to genotype main effects, and Gx L (0.165) and G x Y (0.525) effects were smaller, as estimated by components of variance. These findings are in accordance with those of as Barbieri et al. (1997), Sulman et al. (2003) and Fox et al. (2004). Just as Barbieri at al (1997) reported that the heritability values for the genotypes along the generations analyzed showed that the environment is responsible for $50 \%$. In addition, more recent studies have identified markers for black point. Markers have been identified on chromosomes $2 \mathrm{H}$ and $5 \mathrm{H}$ (Fox et al., 2004). Sulman et al. (2003) also reported levels of heritability from 39 to $70+\%$ in a number of populations suggesting that development of resistance to this grain defect was readily achievable through selection.

\section{Conclusions}

Fourteen durum spring wheat varieties (Triticum $d u$ rum L.) comprising commercial cultivars were studied in the eight different environments, to determine the genotype $\mathrm{x}$ environment interactions and heritability. Genotype $\mathrm{x}$ environment interactions found significant indicated that the black point should be undertaken for several environments. It was showed that black point indicated moderate heritability (49\%). While developing a breeding program for resistance to black point stem from $H$. sati-

Tab. 6 Means and Tukey test of black point percentage (\%) of multi location base on analysis of variance over eight locations in South-eastern Anatolia

\begin{tabular}{|c|c|c|c|c|c|c|c|c|c|}
\hline \multirow{2}{*}{ Cultivars } & \multicolumn{4}{|c|}{$1999 / 2000$} & \multicolumn{4}{|c|}{$2000 / 2001$} & \multirow{2}{*}{ Means } \\
\hline & E1 & E2 & E3 & E4 & E1 & E2 & E3 & E4 & \\
\hline 'A.Toprak-98' & $0.79 \mathrm{~g}-\mathrm{I}$ & 0.001 & $1.54 \mathrm{e}-1$ & $0.24 \mathrm{~h}-1$ & $8.48 \mathrm{bcd}$ & $1.02 \mathrm{e}-1$ & $1.57 \mathrm{e}-\mathrm{k}$ & $0.44 \mathrm{~g}-1$ & $1.76 \mathrm{BC}$ \\
\hline 'Aydın-93' & $0.21 \mathrm{i}-1$ & 0.001 & $0.67 \mathrm{~g}-1$ & $0.11 \mathrm{jkl}$ & $9.58 \mathrm{bc}$ & $0.23 \mathrm{i}-1$ & $0.93 \mathrm{~g}-1$ & $0.21 \mathrm{i}-1$ & $1.49 \mathrm{CD}$ \\
\hline 'Ceylan-95' & $0.23 \mathrm{~h}-1$ & 0.001 & $1.45 \mathrm{e}-1$ & $0.18 \mathrm{i}-1$ & $11.93 \mathrm{abc}$ & $1.15 \mathrm{e}-1$ & $1.28 \mathrm{e}-1$ & $0.43 \mathrm{~g}-1$ & $2.08 \mathrm{BC}$ \\
\hline 'Dicle-74' & $0.55 \mathrm{~g}-1$ & 0.001 & $4.04 \mathrm{def}$ & $0.53 \mathrm{~g}-1$ & $10.83 a b c$ & $1.80 \mathrm{e}-\mathrm{j}$ & $2.10 \mathrm{e}-\mathrm{i}$ & $0.62 \mathrm{~g}-1$ & $2.56 \mathrm{~A}$ \\
\hline 'Dyb.-81' & $0.73 \mathrm{~g}-1$ & 0.001 & $2.26 \mathrm{e}-\mathrm{h}$ & $0.29 \mathrm{~g}-1$ & $9.90 \mathrm{bc}$ & $0.69 \mathrm{~g}-1$ & $1.38 \mathrm{e}-1$ & $0.25 \mathrm{~g}-1$ & $1.94 \mathrm{ABC}$ \\
\hline 'D. 5456 & $0.27 \mathrm{~h}-1$ & 0.001 & $0.97 \mathrm{~g}-\mathrm{l}$ & $0.35 \mathrm{~g}-1$ & $6.85 \mathrm{~cd}$ & $0.75 \mathrm{~g}-1$ & $1.53 \mathrm{e}-1$ & $0.68 \mathrm{bg}-\mathrm{l}$ & $1.42 \mathrm{BC}$ \\
\hline 'Ege-88' & $0.65 \mathrm{~g}-1$ & 0.001 & $0.96 \mathrm{~g}-1$ & $0.11 \mathrm{jkl}$ & $9.75 a b c$ & $1.55 \mathrm{e}-\mathrm{k}$ & $1.40 \mathrm{e}-1$ & $0.37 \mathrm{~g}-1$ & $1.85 \mathrm{BC}$ \\
\hline 'Furat-93' & $0.59 \mathrm{~g}-1$ & $0.04 \mathrm{kl}$ & $1.45 \mathrm{e}-1$ & $0.05 \mathrm{kl}$ & $8.48 \mathrm{bcd}$ & $1.66 \mathrm{e}-\mathrm{l}$ & $1.89 \mathrm{e}-1$ & $0.40 \mathrm{~g}-1$ & $1.82 \mathrm{BC}$ \\
\hline 'Özberk' & $0.13 \mathrm{jkl}$ & 0.001 & $1.32 \mathrm{e}-1$ & $0.47 \mathrm{~g}-1$ & $13.55 \mathrm{ab}$ & $1.52 \mathrm{e}-1$ & $1.53 \mathrm{e}-\mathrm{k}$ & $0.86 \mathrm{~g}-1$ & $2.42 \mathrm{AB}$ \\
\hline 'Gidara-II’ & $0.75 \mathrm{~g}-1$ & $0.08 \mathrm{kl}$ & $2.80 \mathrm{efg}$ & $0.48-\mathrm{g}-1$ & $9.65 b c$ & $1.93 \mathrm{e}-\mathrm{k}$ & $2.07 \mathrm{e}-1$ & $0.80 \mathrm{~g}-1$ & $2.32 \mathrm{~A}$ \\
\hline 'Harran-95' & $0.67 \mathrm{~g}-1$ & 0.001 & $0.76 \mathrm{~g}-1$ & $0.41 \mathrm{~g}-1$ & $9.43 \mathrm{bc}$ & $0.75 \mathrm{~g}-1$ & $1.45 e-i$ & $0.57 \mathrm{~g}-1$ & $1.75 \mathrm{BC}$ \\
\hline 'S. Çanak-98' & $1.40 \mathrm{e}-1$ & 0.001 & $1.13 \mathrm{f}-\mathrm{l}$ & $0.33 \mathrm{~g}-1$ & $11.08 \mathrm{abc}$ & $0.86 \mathrm{~g}-1$ & $2.41 \mathrm{e}-1$ & $0.58 \mathrm{~g}-1$ & $2.22 \mathrm{AB}$ \\
\hline 'Sorgül' & $0.91 \mathrm{~g}-1$ & 0.091 & $0.46 \mathrm{~g}-1$ & $0.22 \mathrm{~h}-1$ & $16.85 \mathrm{a}$ & $1.00 \mathrm{e}-\mathrm{l}$ & $1.41 \mathrm{efg}$ & $0.70 \mathrm{~g}-1$ & $2.71 \mathrm{AB}$ \\
\hline 'Balcali-2000' & $0.24 \mathrm{~h}-\mathrm{I}$ & $0.05 \mathrm{kl}$ & $0.05 \mathrm{kl}$ & $0.13 \mathrm{i}-1$ & $4.08 \mathrm{de}$ & $0.40 \mathrm{~g}-1$ & $0.12 \mathrm{e}-1$ & $0.06 \mathrm{kl}$ & $0.64 \mathrm{D}$ \\
\hline Means \% & 0.58 & 0.02 & 1.42 & 0.28 & 10.03 & 1.09 & 1.50 & 0.50 & \\
\hline
\end{tabular}

*:Means followed by different letters within a column for each year in significant differences at the level of $\mathrm{P}<0.05$ for Tukey Range Test.

Tab. 7. Tab II. Components of variance and broad sense heritability $\left(\mathrm{h}^{2}\right)$ of percentage of black point.

\begin{tabular}{cccccc}
\hline $\begin{array}{c}\text { GxL } \\
\text { variance }\end{array}$ & $\begin{array}{c}\text { variance } \\
\text { variance }\end{array}$ & $\begin{array}{c}\text { GxL } \\
\text { variance }\end{array}$ & $\begin{array}{c}\text { Genotype } \\
\text { variance }\end{array}$ & $\begin{array}{c}\text { Heritability } \\
\%\end{array}$ \\
\hline $0,165^{* *}$ & $0,525^{* *}$ & $2,32^{*}$ & $0,686^{* *}$ & 1,392 & 0,49 \\
\hline
\end{tabular}

vum in the field, it is of fundamental importance to have an efficient environmental control through suitable plot size and large number of replications in various years and sites to allow an increase in the trait heritability (Barbieri et al., 1997). 
96

\section{References}

Adlaka, K. L. and L. M. Joshı (1974). Black point of wheat. Ind Phytopathol 27:41-44.

Agarwal, P. C., K. Anitha, R. Dev, B. Singh and R. Nath (1993). Alternaria alternata, real cause of black point and differentiating symptoms of two other pathogens associated with wheat (Triticum aestivum) seeds. Indian J Agric. Sci. 63:451-453.

Akçura, M., Y. Kaya and S. Taner (2005). GenotypeEnvironment Interaction and Phenotypic Stability Analysis for Grain Yield of Durum Wheat in the Central Anatolian Region Turk J. Agric. For 29:369-375

Ali, N., F. Javidfar and Y. Mirza (2003). Selection of stable rapeseed (Brassica napus L.) genotypes through regression analysis. Pak. J. Bot. 35:175-183.

Anonim, (2001). Devlet Meteoroloji Genel Müdürlüğü, Diyarbakır, Akçakale ve Ceylanpınar Meteoroloji Müdürlükleri Gözlem kayıtları.

Barbieri, R. L., F. I. F. Carvalho, A. I. C. Dornelles, R. M. L. O. Cristaldo and C. L. Handel (1997). Genetics of resistance to the fungus Helminthosporium sativum in wheat: use of culture filtrates in tissue culture. Braz. J. Genet. vol.20 no.3 Ribeirão Preto Sept.

Biçıci, M. and A. Çınar (1988). Çukurova bölgesinde yetiştirilen buğday tanelerinde görülen siyah leke hastalığının etiolojisi ve önemi. $V$. Türkiye Fitopatoloji Kongresi, S. 15, Antalya.

Bhowmınk, T. P. (1969). Alternaria seed infection of wheat. Plant Dis Rep 53:77-80

Conner, R. L. and A. D. Kuzyk (1988). Black point incidence in soft white spring wheat in southern Alberta and Saskatchewan between 1982 and 1987. Can Plant Dis Surv 68:27-31.

Conner, R. L., G. C. Kozub and A. D. Kuzyk (1990). Influence of pollen on black point incidence in soft white spring wheat. Can J Plant Pathol 12:38-42.

Crossa, J. (1990). Statistical analayses of multilocation trials. Advances in agronomy 44:45-85.

Fakır, G. A., M. H. Rahman and G. M. M. Rahman (1989). Survey on the prevalence of black point fungi of wheat in Bangladesh. Bangladesh J Plant Pathol 5:19-29.

Fernandez, M. R., . M. Clarke, R. M. Depauw, R. B. Irvine and R. E. Knox (1994). Black point and red smudge in irrigated durum wheat in southern Saskatchewan in 1990-1992. Can J Plant Pathol 16:221-227.

Fox, G., M. Sulman, V. Johnson, K. Young and A. Inkerman (2004). Strategies for breeding against Barley Grain Colour defects. Proceedings of the 4th International Crop Science Congress. Brisbane, Australia.

Geves, (1994). Bulletin des varietes cereals. La Miniere Guyancourt France.

Greaney, F. J., Hah. Wallace (1943). Varietal Susceptibility To Kernel Smudge İn Wheat. Sci. Agric. 24:126-134
Hebert, Y., C. Plomion and N. Harzic (1995). Genotypic x environment interaction for root traits in maize as analysed with factorial regression models. Euphytica 81:85-92. Brazilian Journal of Genetics.

Khanum, M., Y. Nigar and A. K. Khanzada (1987). Effect of black point disease on the germination of wheat varieties. Pakistan J. Agric. Res. 8:467-473.

Kilpatrıck, Ra. (1968). Factors affecting black point of wheat in Texas, 1964-67. Texas Agric. Exp. Stn. Misc. Publ. 884:311.

Lorenz, K. (1986). Effects of black point on grain composition and baking quality of New Zealand wheat. N.Z. J. Agric Res 29:711-718

Luke, H. H. and H. E. Wheeler (1955). Toxin production by Helminthosporium victoriae. Phytopathology 45:453-458.

Rana, J. P. and P. K. S. Gupta (1982). Occurrence of black point disease of wheat in West Bengal. Ind Phytopathol 35:700702.

Rees, Rg., Dj. Martın and Dp. Law (1984). Black point in bread wheat: effects on quality and germination, and fungal associations. Aust. J. Exp. Agric. Anim. Husb. 24:601-605.

Sabancı, C. O. (1992). Adi fiğde (Vicia sativa L.) bazı tarımsal özelliklerin genotip x çevre interaksiyonu ve kalıtım derecesi tahminleri. Doğa Tr. J. of Agricultural and Forestry 16:797802 TÜBİTAK.

Sağır, A. and C. ve Akıncı (2001). Ekim zamanı ve ekim sıklığ ile buğday embriyo kararması hastalığı arasındaki ilişkinin ve bu hastalığın tohum çimlenmesine etkisinin belirlenmesi. Türkiye IV Tarla Bitkileri Kongresi. Cilt 1, sayfa 231-236 17-21 Eylül 2001 tekirdağ.

SAS Institute Inc. 2002. All JMP, A Business Unit OF SAS. ABD.

Southwell, R. J., P.T.W. Wong and J. F. Brown (1980), Resistance of durum wheat cultivars to black point caused by Alternaria alternata Australian Journal of Agricultural Research 31(6) 1097 - 1101. http://www.publish.csiro. $\mathrm{au} /$ ?paper=AR9801097.

Sönmez, N., A. Sağır and C. Ve Akıncı (2005). Bazı makarnalık buğday ç̧eşitlerinin verim ve verim unsurları ile karabenek ve pas hastalıklarına karşı reaksiyonların belirlenmesi. Türkiye IV. Tarla Bitkileri Kongresi, 5-9 Eylül 2005 Antalya, Cilt 1, sayfa $65-70$.

Sulman, M., K. Fox G Bell and P. Inkerman (2003) Proceeding of the $11^{\text {th }}$ Australian Barley Technical Symposium.

TMO (2009). Turkish Grain Council. www.tmo.gov.tr.

Tunalı, B. and H. Aktaş (1999). Buğdayda başak yanıklığı ve kara benek hastalıkları ve önemi. Orta Anadolu 'da Hububat Tarımının Sorunları ve Çözüm Yolları Sempozyumu. S. 434439, Konya

Zhang, T. Y., H. L. Wang and F. L. Xu (1990). Effects of grain black point disease of wheat and the pathogenic fungi. Acta Phytophy Sinica 17:313-316. 